\title{
Analysis of Universal Preschool Education System in China
}

\author{
Yuhe Tian ${ }^{1, *}$ \\ ${ }^{1}$ Graduate School of Education, University of Pennsylvania, 19104, USA \\ *Corresponding author. Email: yuhetian@gse.upenn.edu
}

\begin{abstract}
China launched the Outline of China's National Plan for Medium and Long-term Education Reform and Development (2010-2020) in 2010 to promote affordability, accessibility, and accountability of preschool education system. Building the system of Puhui kindergarten is embraced as a main approach. Therefore, the author intends to analyze practices and implementation of this ambitious plan and identify factors that hinder further reform in China by reviewing literatures on development of Puhui kindergarten. The analysis mainly focuses on the reaction of various stakeholders to Puhui kindergarten, especially private kindergarten owners and parents. The author found that less profits and authorities are the main factors keep private owners out of participation and the quality of Puhui kindergarten are concerned by parents. Thus, the development of universal preschool education system keeps in an ongoing process at the initial stage. In addition to the expansion of quantity, kindergarten in China should consider more about its quality in an age-appropriate way, especially Puhui kindergarten, which requires more funding and training supports. Furthermore, government is expected to give parents more choice by encouraging the development of kindergartens that differ in education ideas and pedagogies, for creating a performance evaluation system to ensure the sustainability and effectiveness of Puhui kindergarten system. Lastly, more well-designed and hands-on teacher training program are needed for improving the quality of teaching staff in kindergarten.
\end{abstract}

Keywords: Preschool education system, Puhui Kindergarten, Policy and practice, Limiting factor, China

\section{INTRODUCTION}

Since 2010, a great amount of efforts has been made to promote the universal preschool education system in China. Chinese government issued a series of policies to improve the accessibility, affordability and accountability of kindergarten for children from age 3 to 6. Thus, a new type of kindergarten named Puhui Kindergarten, came into being, which differs from traditional ones in terms of its management, sponsorship and monitoring mechanism. Puhui is a two-character word in Chinese, which jointly means universal and affordable kindergarten for all eligible children. In 2020, Puhui kindergarten accounts for $84.74 \%$ of all 28,1174 kindergartens nationwide [1] and increased by $17.5 \%$ compared to 2016 [2]. Accordingly, the preschool education enrollment was considerably increased from $34,244,500$ in 2011 to $47,138,810$ in 2020 , and the gross enrollment rate increased from $62.3 \%$ in 2011 to $85.2 \%$ in 2020 [3]. From numbers, the implementation of Puhui kindergarten has remarkably involved children of school age into the national preschool education system, and improved equity of access to kindergarten for Chinese families to some extent. However, the real scenario might be different. A study surveyed 27,515 Chinese parents randomly sampled from 12 cities of China indicated that Puhui kindergarten is less attractive to them, despite its merits of universalization and low cost [4]. Thus, this paper aims to examine current practice of Puhui Kindergarten and the related national policies, and to identify obstacles in building an efficient universal preschool system in China. The author intends to offer an outlook on what factors should be further considered to involve and motivate multiple stakeholders in this process. Additionally, the author hopes to put forward some suggestions for the development of preschool education system. 


\section{ANALYSIS}

\subsection{Definition of Puhui and the general context}

Before the concept of Puhui kindergarten born in 2010, kindergartens were normally classified into three types, including public kindergarten run by the educational department, public kindergarten run by noneducational department, such as governmental organizations or public enterprises, and private kindergarten with license. Figure 1 shows the number of children enrolled in kindergarten in China from 2016 to 2020. The first two types are commonly considered to have better quality in teaching, facilities and other resources than private counterparts, since they are owned, sponsored and monitored by educational authorities and other governmental organizations [4]. Additionally, the tuition fee and other costs of public kindergarten are regulated by governments, so enrollment in pubic kindergarten is a more economic choice for Chinese families. However, the quantity of public kindergarten is limited, and its enrollment tilts towards higher-income families in urban areas. To address " $3 \mathrm{~A}$ " problems in preschool education system-accessibility (hard to get into a kindergarten), affordability (more expensive than university), and accountability (poor quality and no monitoring system), the idea of Puhui kindergarten is proposed.

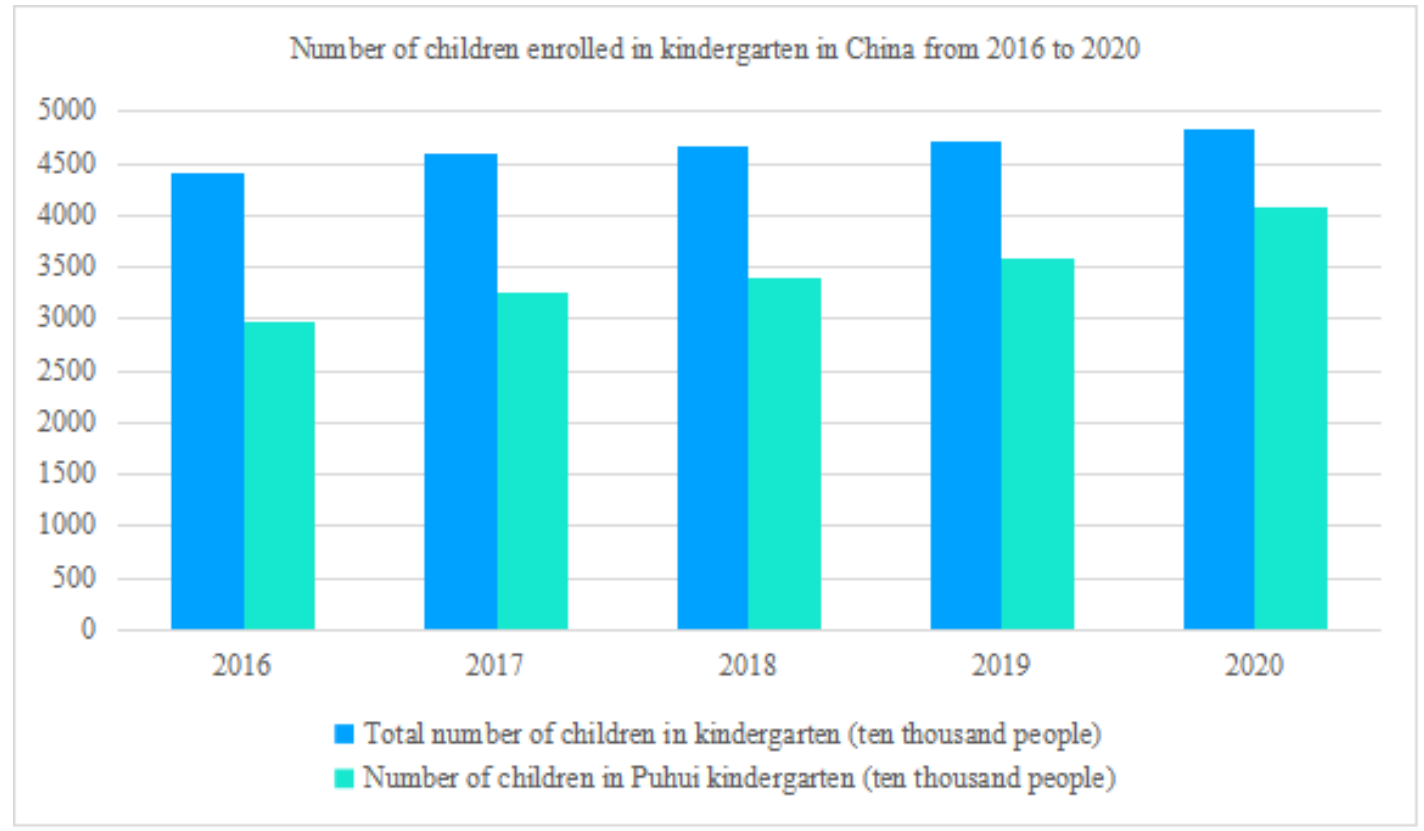

Figure 1 Number of children enrolled in kindergarten in China from 2016 to 2020

Puhui kindergarten especially stands for the kindergarten that provides universal and affordable preschool education for public interest. This new type of kindergarten is a mix of both public and private sectors. It is either public kindergarten held by government or other non-educational institutions, or private kindergarten authorized by government with the support of subsidies on early childhood education. The latter that owned by individuals or private organizations needs to be monitored, regulated and evaluated by government in terms of curriculum, tuition fee and other aspects. As for the existing kindergartens, all public kindergartens are automatically involved into the Puhui preschool education system and are expected to play a leading role in the whole system. Private ones are welcomed to join the Pukui system by getting qualification and approval from local government to provide quality services.

\subsection{Obstacles in developing Puhui Kindergarten System}

\subsubsection{Resistance from private kindergarten}

Although private kindergartens are "voluntarily" join into the system, government set the goal of transforming most of existing private kindergarten into Puhui private kindergarten according to official document. This progressive policy actually changes private kindergarten into quasi-public kindergartens, which confronted with resistance from private owners. Historically, private kindergartens are market-driven and self-funded private institutions [5]. They are allowed to set and charge tuition fees based on their own costs, which is the largest part of income. If they choose to be this new type of quasi-public kindergarten, their tuition fee would have to be significantly reduced under government regulation. Less profits leave to private owners, and some even have 
to run with loss since the financial subsidy from local government cannot fully compensate their cost [6].

Meanwhile, less authority leaves to private owners in managing their kindergartens as well. In the past, the municipal government usually adopted a laissez-faire policy for private kindergartens, which gives them large freedom in funding, curriculum, environment and personnel. They only received the quality evaluation by local educational authorities on a voluntary basis [7]. Being a Pukui private kindergarten means a joint effort with local government and a clash between different educational ideas, conflict and contradiction of interest, while government is absolutely the leading role in this process. The responsibility of monitoring largely shifts from market to government for private owners, who would have less authority in deciding the running of their "little kingdoms". Studies show that some private kindergartens were asked to change the curriculum plan and class size after being transformed into Puhui kindergarten. Therefore, this top-down policy with a good intention to achieve equity in preschool education seems idealistic. This governmental intervention into the privately-owned sector that received reluctance indicates that landscape of preschool education in China might not be easily changed, since private owners are more concerned about profits.

\subsubsection{Parents' Attitudes to Inclusive Kindergartens}

Reactions from Chinese parents towards Puhui kindergartens are also unsatisfactory, which raise doubts about the effectiveness of Puhui system. According to the related study, public kindergarten remains the most desirable ones to parents, whereas Puhui kindergarten received the least satisfaction as well as those ordinary private kindergarten. The foremost problem that parents are concerned about is the quality of education itself, though Puhui private kindergarten indeed helps lessen the economic burden, especially for disadvantaged families. Regulation on tuition fee and inadequate subsidy scared many profit-driven investors away. The decline of funding impedes Puhui private kindergarten to increase the number of teachers, improve teaching quality and learning environment.

The public funding distributes to public kindergarten makes the competition even more unfair. Taking Beijing as an example, public kindergarten receives most of public funding by various local educational authorities with only $20 \%$ of all eligible children enrollment in city, so that they could charge a low price and still provide higher quality education, which makes them more attractive to parents [7]. To increase profit or reduce loss, Puhui private kindergartens manage to reduce costs in many ways, including expanding enrollment, increasing class size, reducing the expenditure of toys and teaching aids, decreasing or cancel teacher training program and teacher welfare. Thus, being a Puhui kindergarten means the downgrade of education level and quality to some degree. For instance, some Puhui private kindergarten are found to mainly teach contents, which is not aligned with the cognitive development of children at that age [8].

Moreover, a study surveyed private kindergartens in 17 provinces in China found that low-end kindergartens are most willing to transform into Puhui private kindergarten due to its limited resources and disadvantaged status in the market. Getting government subsidies is the primary reason for them to join the Puhui system [9]. Whereas, Middle-level and high-end private kindergarten show less and least willingness to be involved into the Puhui system respectively. Consequently, Puhui system contains a considerable number of private kindergarten that are low in running and teaching quality. If parents are not able to send child to a public kindergarten, and they still want high-quality preschool education, their choice might be those highend private kindergarten with super-expensive tuition fee [10]. Since the success of implementing curriculum and pedagogical models, such as constructivist curriculum and student-centered pedagogy, put high demands on funding, teacher qualification, teacher-student ratio and other resources. As figure 2 displayed, the increasing number of middle-level and high-end private kindergarten, during the building of Puhui kindergarten system, supports this argument and indicates the high need for good quality still exist among households in the market. In this way, choices for kindergarten with relatively good quality and fair price actually shrink. Government intervention in this private sector increase the disparities among private kindergarten with different customer groups, which makes Puhui private kindergarten less attractive to parents and forces parents to pay more for choices. 




Figure 2 Number of different types of private kindergarten in 17 provinces in China, 2017-2018

\subsubsection{Problems of teaching staff in both Puhui public and private schools}

Under the academic pressure of the whole education system in China, preschool education is commonly regarded by teachers and some parents as training and preparation for assessment. The content of learning is beyond children's development stage, which largely emphasizes on knowledge and skills, and some kindergartens even plan the courses according to subjects taught in primary school. Since the curriculum reform, the child-oriented and student-centered approaches are applauded [11]. It encourages children to take learning into their own hands, as opposed to being directed or prompted by a teacher. However, this approach pays more attention to the need and interest of each individual, and the quantity of experienced teacher is in demand.

For many teachers in kindergarten, knowing new theories does not mean knowing how to practice in a real educational scenario. Some complains that teaching becomes more difficult under this approach since it requires more on observing, thinking, deciding and responding in a student-led class, especially most of teachers are under junior college degree and not majored in early childhood education. Teachers in Puhui private kindergarten are even found to have lower educational qualifications than those in public kindergarten. Disqualified teachers without systematic training provided by kindergarten or educational institutions to understand pedagogical principles have difficulties in implementing new curriculum and providing education with good quality.

Furthermore, teacher shortage is another problem, especially for the high-quality teachers. National statistics show that the number of full-time faculty in kindergarten nationwide reached 2,580,000 at the end of
2018 , increased of $145 \%$ compared to 2010 . However, a vacancy of 520,000 still exists according to the standard of "two teachers and one care-giving worker for one class" [12]. This indicates the number of faculty in kindergarten still cannot meet the demand despite it has achieved leapfrog growth in recent years. Low socioeconomic status, excessive workload, unclear job development path, low sense of achievement and identity, all contribute to the scarcity in teacher quantity. As for existing teachers, they have relatively low loyalty and tend to change the workplace for better treatments in labor market. Mobility is found to be higher in Puhui private kindergartens than public counterparts in that teacher in private kindergarten do not belong to staffing of national institutions. Teacher turnover is found negatively associated with the cohesiveness and effectiveness of school communities by disrupting educational programs and professional relationships that intend to improve student learning. Thus, increasing the number of qualified teachers and keeping them in profession are vital for developing a high-quality and stable universal preschool education system in China.

\section{DISCUSSION}

This study examines literature on implementation of universal preschool education system in China since 2010 in an attempt to identify factors that hinder further development on this child welfare service. Three major factors are reluctance of private kindergarten, low quality of Puhui private kindergarten and problems of teaching staff in both Puhui public and private schools. In this section, suggestions and policy recommendations on how to improve these problems are provided.

Firstly, policy makers should develop a shared understanding among stakeholders, and engage in public kindergarten, private owners, parents and the community 
to roll out initiative. Government should reconsider the definition of Puhui. There have been some misunderstandings that Puhui kindergarten is all about low tuition fee among society and policy makers. A sustainable Puhui system should consider the quality and its important charitable role of reducing family burden. Additionally, government should ensure the plan of Puhui system is feasible and effective. If incentives are inadequate, only private kindergarten with low quality and low profits are willing to be a Puhui kindergarten and stay in this system, while those with good quality and high profits would prefer free market to maximize their gains. Thus, more incentive programs should be designed to specifically support Puhui private kindergarten. In addition to subsidy, government should establish a systemic supporting framework to help private kindergartens that are willing to transform into charitable Puhui type, then keep tracking on their performance to examine whether they are aligned with Puhui principle. Public funding should be more tilted towards existing Puhui private schools rather than obsessed with building new public kindergartens.

What is more, although government has the responsibility to monitor the management and performance of Puhui kindergarten, development of kindergarten with different education concepts and teaching method should be encouraged. It is impossible to require all kindergartens have the same approach and practice like products in assembly line, even though they are included in the Puhui system and receive subsidies from government. Chinese families have the right to choose the most suitable kindergarten that are aligned with their value. To prevent the extremely high-pricing kindergarten, which potentially impedes social justice, policy makers could look at the practice from Hong Kong, where government classified kindergarten into non-profit-making kindergartens (NPMKs) and independent kindergartens (PIKs). The former receives public subsidy, but both of them are regulated on the net profits by government (NPMKs cannot exceed 5\% per year, PIKs less than 10\%) [13]. In such a way, parents could gain more freedom in choosing schools and decide what kind of education their children should receive. Government could monitor the services provided by private kindergartens by establishing a comprehensive evaluation and assessment to examine the effectiveness and improve accountability.

Teacher quality is identified as the most important school-related factor that influencing student achievement. In the past, the training for teachers in kindergarten is largely focus on skills and knowledge, such as singing, painting and playing. More welldesigned programs that provide understanding of education theory, and methods of teaching should be offered to all public and private kindergartens. Teachers should not only improve their skills, but also deepen the comprehension on child development and education and improve self-efficacy in the field of practice and preparation. Moreover, teacher salary should be improved for them to gain better social status, meanwhile keeping them motivated at work. A reasonable pay would improve the life security of practitioners and make them stick to their career choice.

\section{CONCLUSION}

Since the movement of Puhui kindergarten began, China has reached the consensus on the importance of preschool education at the national level. More public kindergartens are being built and many private kindergartens are transformed into Puhui kindergartens, which dramatically increases the number of overall quantity and successfully improve the equity of access to preschool education for Chinese families to some extent. However, problems exist and are waiting to be solved in the plan of universalizing preschool education, including leveraging the interest of private owners, improving the quality of Puhui private kindergarten to attract more families and achieve equity in the real sense, and improving quality of teaching staff to ensure the successful implementation of curriculum and pedagogy. However, this study has several limitations. Firstly, a more multidisciplinary perspective should be adopted to analyze the nature of preschool education system in China, including economics, sociology and demography approach, to minimize one-sided opinion. Secondly, due to the great diversity of social customs and variety in economic development among different regions in China, more research of assessment on Puhui kindergarten in economically underdeveloped areas should be looked through to demonstrate a full scenario of development in preschool education in China. Thirdly, there is no evaluation data on how Puhui kindergarten performed in the past decade. Therefore, further study should develop a standard of early children outcome to evaluate the effectiveness and performance of Puhui kindergarten.

\section{ACKNOWLEDGMENTS}

First and foremost, I would like to show my deepest gratitude to my teachers, who have provided me with valuable guidance in every stage of the writing of this thesis. Further, I would like to thank my parents for their encouragement and support. Without all their enlightening instruction and impressive kindness, I could not have completed my thesis.

\section{REFERENCES}

[1] Ministry of Education, 2020. 2019-2020 Basic Statistics of Pre-primary Education (Total). Online available, http://jyt.fujian.gov.cn/xxgk/tjsj/202008/. Retrieved on April 26, 2021.

[2] Ministry of Education, 2016. National Education Statistic Report. Online available, 
http://www.moe.gov.cn/jyb_xwfb/s5147/202103/t2 0210302_516418.html. Retrieved on April 26, 2021.

[3] Ministry of Education, 2011. National Education Statistic Report. Online available, http://www.moe.gov.cn/srcsite/A03/s180/moe_633/ 201208/t20120830_141305.html. Retrieved on April 25, 2021.

[4] Hong, X., Zhu, W., Wu, D. and Li, H., 2019. Are Parents Satisfied with Early Childhood Education Service in Urban China? Empirical Evidence from the Validation Study of the Parent Satisfaction with Educational Experiences Scale. Early Education and Development.

[5] Zhou, Y., Li, H., Hu, B. and Li, L., 2017. On the road to universal early childhood education in China: A financial perspective. International Journal of Educational Development, pp. 137-144.

[6] Zhou, Y., Jiang, Y., Zheng, C. and Li, H., 2020. Is puhui kindergarten a panacea for the ' $3 \mathrm{~A}$ ' problems of early childhood education in China? Evidence from a national validation study. Children and Youth Services Review.

[7] Liu, Y. and Pan, Y. J., 2013. A review and analysis of the current policy on early childhood education in mainland China. International Journal of Early Years Education, pp. 141-151.

[8] Li, H. and Huang, W., 2021. Development research on Puhui kindergarten: Review and outlook. Journal of Henan Institute of Science and Technology.

[9] Wang, H., Liu, J. and Wei, C., 2020. The dilemma and approach of private kindergartens: universal or profitable?. The Development of Early Child Education.

[10] Li, H., Yang, W. and Chen, J. J., 2016. From 'Cinderella' to 'Beloved Princess': The Evolution of Early Childhood Education Policy in China. International Journal of Child Care and Education Policy.

[11] Zhu, J. and Zhang, J., 2008. Contemporary trends and developments in early childhood education in China. Early Years: An International Research Journal, pp. 173-182.

[12] Ministry of Education, 2019. 2019 Annual Report on Preschool Education in China. Online available, http://www.moe.gov.cn/jyb_xwfb/s5147/202002/t2 0200203_417501.html. Retrieved on April 25, 2021.

[13] Li, H., Wong, J. M. S. and Wang, C. X., 2010. Affordability, accessibility, and accountability: Perceived impacts of the Pre-primary Education Vouchers in Hong Kong. Early Childhood Research Quarterly, pp. 125-138. 